UDC 94(47+57)«1940/1953»

Submitted: 15.09.2017

LBC 63.3(235)6

Accepted: 21.11.2017

\title{
STRATEGIES FOR SURVIVAL OF THE ORTHODOX CLERGY OF THE ROSTOV REGION DURING THE GREAT PATRIOTIC WAR
}

\author{
Alla V. Shadrina \\ Southern Scientific Center of RAS, Rostov-on-Don, Russian Federation
}

\begin{abstract}
The paper shows the survival strategies of the parish clergy of the Rostov region during the Great Patriotic War. In the pre-war period, the clergy was disjointed and did not represent a single social group due to the repressive policy of the Soviet state. In order to survive, priests were forced to work in state institutions, on collective farms, to engage in unskilled labour. Part of the clergy, preserving their priestly dignity, refused to work in Soviet institutions and lived at their children's expense. During the Great Patriotic War the situation began to change. Prior to the occupation of the Rostov region, clergymen continued to work in state structures, but some of them began to return to the priesthood in the churches that were opened on the initiative of the parishioners. A radical turning point occurred during the occupation. The policy of the occupation authorities aimed at the formation of diocesan departments, considered by the invaders to be the instrument of ideological influence on the population, and the mass opening of churches, stimulated the return of priests to performing divine services, and supported new consecrations. These circumstances caused the replenishment of the clergy ranks by random people who treated the adoption of the sacred dignity as a way of survival. Some of the clergy refused to return to the priesthood, partly out of disagreement with the leaders of the newly formed diocesan departments supporting the invaders, partly because of the fear of the return of Soviet power and possible repression. The period of occupation, despite the mass opening of churches, was rather a pseudo-revival of the Russian Orthodox Church, to which the initiating priests tried to impose anticanonical administration. The formation of the diocesan life in the Rostov diocese established in 1943 began only after the appointment of Bishop Eleutherios (Vorontsov) as the ruling bishop, who played the key role in the formation of the clergy.
\end{abstract}

Key words: clergy, survival strategies, Russian Orthodox Church, Great Patriotic War, religious policy of the invaders, diocesan administrations in the Rostov region during World War II.

Citation. Shadrina A.V. Strategies for Survival of the Orthodox Clergy of the Rostov Region during the Great Patriotic War. Vestnik Volgogradskogo gosudarstvennogo universiteta. Seriya 4, Istoriya. Regionovedenie. Mezhdunarodnye otnosheniya [Science Journal of Volgograd State University. History. Area Studies. International Relations], 2018, vol. 23, no. 1, pp. 79-90. (in Russian). DOI: https://doi.org/10.15688/jvolsu4.2018.1.8

УДК 94(47+57)«1940/1953»

Дата поступления статьи: 15.09.2017

ББК $63.3(235) 6$

Дата принятия статьи: 21.11.2017

\section{СТРАТЕГИИ ВЫЖИВАНИЯ ПРАВОСЛАВНОГО ДУХОВЕНСТВА РОСТОВСКОЙ ОБЛАСТИ В ГОДЫ ВЕЛИКОЙ ОТЕЧЕСТВЕННОЙ ВОЙНЫ}

\author{
Алла Валерьевна Шадрина \\ Южный научный центр РАН, г. Ростов-на-Дону, Российская Федерация
}




\section{СТАЛИНГРАДСКИЙ ТЫЛ}

священнослужению в открывавшиеся по инициативе прихожан церкви. Коренной перелом наступил во время оккупации. Политика оккупационных властей, направленная на формирование епархиальных управлений, в которых захватчики видели инструмент идеологического воздействия на население, и массовое открытие церквей, стимулировала возвращение к совершению богослужений священников довоенного поставления и поддерживала новые хиротонии. Эти обстоятельства стали поводом для пополнения рядов духовенства случайными людьми, видевшими в принятии священного сана способ выживания. Часть духовенства отказалась возвращаться к священнослужению частично из несогласия с руководителями новообразованных епархиальных управлений, поддерживавших оккупантов, частично по причине страха возвращения советской власти и возможных репрессий. Период оккупации, несмотря на массовое открытие церквей, был, скорее, псевдовозрождением Русской православной церкви, которой инициативные священники пытались навязать антиканоническое управление. Становление епархиальной жизни в учрежденной в 1943 г. Ростовской епархии началось только после назначения в качестве правящего архиерея епископа Елевферия (Воронцова), которому принадлежала основная роль в формировании клира.

Ключевые слова: духовенство, стратегии выживания, Русская православная церковь, Великая Отечественная война, религиозная политика оккупантов, епархиальные управления в Ростовской области в годы ВОВ.

Цитирование. Шадрина А. В. Стратегии выживания православного духовенства Ростовской области в годы Великой Отечественной войны // Вестник Волгоградского государственного университета. Серия 4, История. Регионоведение. Международные отношения. - 2018. - T. 23, № 1. - C. 79-90. - DOI: https://doi.org/ 10.15688/jvolsu4.2018.1.8

Формирование в годы Великой Отечественной войны такой социальной группы, как духовенство Русской православной церкви, подвергавшейся в 1920-1930-е гг. уничтожению, в том числе и физическому, является одной из актуальных проблем социальной истории. Особенный интерес представляют ранее не исследовавшиеся вопросы стратегий выживания священнослужителей Ростовской области, причины их возвращения или отказа от возвращения к священнослужению в годы Великой Отечественной войны. Обращение к этим темам позволит выявить особенности формирования новой социальной группы православного духовенства на региональном уровне.

Историография, посвященная проблемам истории Русской православной церкви в годы Великой Отечественной войны, обширна. Она освещена в работах М.В. Шкаровского [60] и В.Н. Якунина [62]. Анализу взаимодействия духовенства с оккупационными властями в годы Великой Отечественной войны и проблеме коллаборационизма посвящена работа иеродиакона Платона (Рожкова) [12]. Просветительской деятельности и пастырскому служению посвящены исследования О.А. Бабичевой [1] и В.В. Калашника [5]. Участие духовенства в движении сопротивления и военных действиях рассматривается в работах С.В. Кулик и Е.А. Самыловской [8] и О.В. Назаровой [11].
Значительный интерес представляют региональные исследования, посвященные проблемам религиозного возрождения в годы Великой Отечественной войны на территории Нижней Волги, Дона и Ростовской области [7; $10]$, патриотической деятельности $[46 ; 55]$, особенностям церковной жизни в период оккупации [4; 54; 56; 57], а также православному духовенству этого региона $[9 ; 47 ; 59 ; 63]$.

Основу источниковой базы настоящего исследования составляют анкеты служителей культа, заполнявшиеся или писавшиеся священнослужителями в свободной форме в связи с регистрацией в 1944-1946 гг. церковных общин уполномоченным Совета по делам Русской православной церкви при Совете министров СССР по Ростовской области. Анкеты входят в состав регистрационных дел церквей и являются источником, дающим представление о персоналиях священнослужителей Ростовской области периода Великой Отечественной войны и позволяющим провести анализ разных сторон их жизни и деятельности.

К началу Великой Отечественной войны Русская православная церковь фактически перестала представлять собой организацию: она была лишена прав юридического лица, собственности и права ее приобретать [50, с. 10 , 20-35]; на свободе осталось лишь 4 епископа [50, с. 296]; из 50 тыс. православных храмов к 1941 г. осталось 350 действующих церквей, не учитывая присоединенные в 1939 г. террито- 
рии [61, с. 19]. Эпоха Большого террора стала причиной миграции и значительного сокращения численности духовенства, причем репрессиям подвергались не только служившие священники, но и те, которые перешли на службу в государственные учреждения.

Репрессивная политика советского государства заставила священнослужителей искать стратегии выживания. Анализ анкет духовенства Ростовской области позволяет сделать выводы о том, что в довоенный период священники, лишившиеся места служения главным образом по причине закрытия церквей, либо искали место служения в другом храме, либо переходили на работу в государственные учреждения. При этом важно отметить, что такие священники не снимали сан. Их положение можно квалифицировать как выход «за штат», предполагающий беспрепятственное возвращение к священнослужению в любое время. Учитывая обстоятельства времени, такое решение проблемы не расценивалось как антиканоническое с точки зрения Церкви.

Изучение анкет позволило выявить следующие стратегии выживания духовенства в довоенный период:

1) переход на службу в государственные учреждения, в том числе на фабрики и заводы, часто в качестве счетных работников и бухгалтеров. Значительно реже «бывшие» священники принимались на работу в качестве учителей [25, л. 11-11 об.; 39, л. 9-9 об.; 40, л. 10];

2) работа в колхозах [26, л. $7 ; 28$, л. 10 , 26; 38, л. 9];

3) исполнение неквалифицированных работ [41, л. 50];

4) незначительная часть духовенства 7,6 \% [59, с. 233] - предпочла не сотрудничать с государством. Такие священнослужители жили на иждивении своих детей [17, л. 71-71 об.; 44, л. 14-14 об.];

5) также незначительная часть священнослужителей в 1940-1941 гг. проходила адаптацию после пребывания в исправительно-трудовых лагерях. Как правило, они тоже жили на иждивении своих детей или родственников, не предпринимая поиска работы в советских организациях [36, л. 8-8a].

Избранные духовенством стратегии выживания обусловили тот факт, что к началу
Великой Отечественной войны донское духовенство было разрозненно и не представляло собой единой социальной группы.

Великая Отечественная война стала причиной изменения социального статуса православного духовенства, прежде всего, потому, что священники оказались востребованными в связи с массовым открытием храмов в период оккупации. В Ростовской области к 1941 г., согласно официальным данным, осталась действующей только одна церковь [52, л. 1], хотя анализ регистрационных дел показал, что помимо нее, богослужения продолжались еще в 4 храмах. В 1941 г. по инициативе верующих были открыты еще 3 храма [53, с. 172-174]. В 1941 г. к священнослужению вернулось 5 священников [14, л. 10; 15 , л. 55-55 об.; 20, л. 11; 27, л. 35-35 об.; 32, л. 7]. К 1941 г. относятся сведения о том, что священнослужители, еще не вернувшиеся к служению в храмах, совершали по просьбе прихожан обряды и таинства на дому [18, л. $25-25$ об.].

Нехарактерным для священнослужителей, но объяснимым с точки зрения стратегий выживания было решение трех священников Ростовской области принять участие в боевых действиях, несмотря на священный сан. Так, священник 1920 г. хиротонии В. Соколов прошел с действующей армией всю войну в качестве медстатиста и был награжден 4 медалями [43, л. 42-42 об.]. Священник 1931 г. хиротонии (обновленческой) И. Рождественский до 1943 г. служил рядовым действующей армии, был ранен, получил звание ефрейтора и после выздоровления вернулся к исполнению священнических обязанностей [13, л. 16-16 об., 78-78 об.]. Священник 1932 г. хиротонии И. Семенов служил разведчиком $[35$, л. 6,7$]$.

Кардинальные изменения в положении священнослужителей произошли во время оккупации. Этому не в последнюю очередь способствовала политика оккупационных властей, которые Церковь и духовенство рассматривали как своих потенциальных союзников $[6$, с. $473 ; 7$, с. $101 ; 12$, с. 216$]$.

Для религиозной политики оккупантов в Ростовской области было характерно два направления: организация епархиальных управлений, подконтрольных немцам, и стимуляция массового открытия церквей. С разрешения 


\section{СТАЛИНГРАДСКИЙ ТЫЛ}

немецких властей в 1942 г. были образованы три епархиальных управления - в Ростове-наДону, Новочеркасске и Таганроге. В Ростове-на-Дону епархиальное управление, которое получило название Управление благочинного при кафедральном соборе, было образовано протоиереем В. Сериковым в сентябре 1942 г. по приказу немецких властей для руководства церквами оккупированных территорий Кавказа, Кубани и Дона [58, с. 1]. В Новочеркасске епархиальной жизнью управлял Новочеркасский благочиннический совет [23, л. 37-37 об.] во главе с благочинным протоиереем М. Долговским [21, л. 23-23 об.]. В Таганроге епархиальное управление возглавил епископ Иосиф (Чернов).

Епархиальные центры играли большую роль, во-первых, в призыве к возвращению к служению священников, работавших до войны в советских учреждениях, и их распределению по открывающимся храмам, во-вторых, в хиротониях священнослужителей, которые совершали епископ Николай (Амассийский), неканонически возглавивший ростовское управление, и епископ Иосиф (Чернов). В-третьих, епархиальные управления использовались оккупантами в качестве идеологических центров [57, с. 371]. Представители епархиальных управлений совершали молебны о победе немецкого оружия [2, с. 1] и выступали в местной прессе с публикациями, исполненными благодарностями фашистам $[51$, c. 1]. Пронемецкая позиция руководителей ростовского управления благочинного вызвала неоднозначную оценку ростовского духовенства [41, л. 8].

Оккупация, несмотря на предоставленную возможность священнослужителям вернуться к совершению богослужений, диктовала свои стратегии выживания. Священник П. Горгулевский писал: «Оккупация застала меня в Новочеркасске. В течение $2 \frac{1}{2}$ мес. я скрывался... Когда дальше стало невозможно скрываться, чтобы спасти себя и семью, вынужден был поступить на службу в церковь» [39, л. 9-9 об.]. Протоиерей Д.К. Яровой в октябре 1942 г. «невольно поступил служить, ибо нечем было жить» [31, л. 10-10 об.]. Протоиерей М.Б. Молчанов писал, что во время оккупации «вынужден был врагами отправлять религиозную службу» [29, л. 10].
В период оккупации в Ростовской области было открыто около 200 церквей [53, c. 174]. В их открытии часто определяющее значение играла инициатива прихожан, приглашавших священнослужителей по своему усмотрению. Как правило, они обращались к священникам, проживавшим в их местности [19, л. 6 ; 22, л. 7, 27-27 об.; 30; 45, л. 9-10]. В некоторых случаях такие обращения, не контролируемые епархиальной властью, были причиной приглашения «людей порочных и отрекавшихся при советской власти от Бога и от Св. Церкви» [7, с. 102].

Помимо возвращения к священнослужению, значительное число священников, ожидая возвращения Красной Армии и советской власти, предпочитали оставаться «за штатом» [17, л. 71-71 об., 104-104 об.; 30, л. 88 об.; 34, л. 24-24 об.], боясь быть уличенными в сотрудничестве с оккупационными властями. Они вышли на церковную службу только после освобождения Ростовской области от оккупантов.

В 1942 и 1943 гг. к священнослужению, согласно анкетам, вернулся и был вновь рукоположен 141 священник: 98 человек в 1942 г. и 43 человека в 1943 году. Можно выделить следующие стратегии выживания донского духовенства периода оккупации:

1) возвращение к священнослужению и принятие священного сана по призыву епархиальных управлений, подчинявшихся оккупационным властям;

2) возвращение к священнослужению и принятие священного сана по благословению епископа Иосифа (Чернова);

3) возвращение к священнослужению по просьбе прихожан;

4) принятие священного сана, связанное с необходимостью легализации и необходимостью гарантированного заработка;

5) отказ от возвращения к священнослужению по причине боязни быть уличенными в сотрудничестве с оккупационными властями и страха возмездия со стороны советской власти.

После освобождения Ростовской области от немецко-фашистских захватчиков церковная жизнь на короткое время пришла в упадок: епископ Николай (Амассийский) и протоиерей В. Сериков ушли с отступавшими войс- 
ками оккупантов. Перед этим они предприняли неудачную попытку перевести ростовское духовенство в юрисдикцию Румынского патриарха. Епископ Николай уехал в Румынию, где умер в возрасте 90 лет [57, с. 372]. Протоиерей В. Сериков выехал в Мариуполь к дочери, где в 1944 г. был арестован НКВД и приговорен к отбыванию срока в исправительно-трудовом лагере, откуда не вернулся. 20 марта 1943 г. особым посланием Патриаршего местоблюстителя митрополита Сергия (Страгородского) архиепископ Николай и протоиерей В. Сериков были осуждены за связь с гитлеровцами [49, с. 45].

По завершении оккупации духовенство, еще хорошо помнившее Большой террор, прекратило совершать богослужения [7, с. 104]. Только после официального изменения церковной политики советского правительства в 1943 г. [48, с. 295] началось становление канонически организованной церковной жизни в Ростовской области. Этот период связан с именем епископа Елевферия (Воронцова) [3]. Именно ему принадлежала основная роль в формировании клира Ростовской епархии 19431944 гг., в том числе в принятии в клир кающегося обновленческого духовенства [59, с. 234].

1944 г. характеризуется очень незначительным пополнением приходского духовенства (13 человек). Начиная с апреля 1943 г. духовенство и верующие Ростовской епархии включились в сбор средств «на победу». До июня 1944 г. было собрано 3160184 руб. [46, c. 118-121]. Наиболее выдающуюся роль в патриотической деятельности сыграл протоиерей г. Шахты И. Васильев. По его инициативе были собраны средства и построен танк «имени Православных Дона» [45, л. 99]. Священник И. Колесников собрал и передал на оборону страны 48000 руб. [33, л. 113 об.]. Священник Л. Тамаров из личных средств внес 8000 руб. на танк, 1000 руб. семьям, пострадавшим от немецких оккупантов [16, л. 9 об.]. Священник П. Горгулевский внес 1000 руб. «на раненых» [39, л. 9-9 об.]. Активная патриотическая деятельность духовенства также может пониматься как стратегия выживания - попытка реабилитироваться за возвращение к священнослужению в годы оккупации.

Как видно, православное духовенство Ростовской области в годы Великой Отече- ственной войны избирало различные стратегии выживания: от возвращения к священнослужению, причем не всегда по призванию, до отказа от исполнения священнических обязанностей, не в последнюю очередь обусловленного страхом перед советской властью. Стратегии выживания выбирались священнослужителями в зависимости от ситуации, но этот выбор часто был показателем степени их зрелости и нравственности. Ряд священнослужителей поддержали оккупантов, пытаясь с их помощью возродить уничтоженную в 1920 1930-е гг. епархиальную власть. Однако их антиканонические действия не имели успеха. Епархиальное управление было учреждено только в 1943 году. Тем не менее именно во время оккупации разрозненное духовенство стало постепенно формироваться в качественно новую социальную группу, объединенную по профессиональному признаку.

\section{СПИСОК ЛИТЕРТУРЫ}

1. Бабичева, О. А. Просветительская деятельность и пастырское служение православного духовенства в годы Великой Отечественной войны / О. А. Бабичева // Вестник магистратуры. - 2016. № 12 (63). - С. 49-52.

2. Вечная память убиенным // Голос Ростова. - 1942. - № 8. - С. 1 .

3. Галкин, А. К. Указы и определения Московской Патриархии об архиереях с начала Великой Отечественной войны до Собора 1943 г. / А. К. Галкин. - Электрон. текстовые дан. - Режим доступа: http://www.sedmitza.ru/text/413984.html (дата обращения: 20.07.2015). - Загл. с экрана.

4. Журавлев, Е. И. Немецкий оккупационный режим и религиозный вопрос на Юге России в годы Великой Отечественной войны / Е. И. Журавлев // Научные проблемы гуманитарных исследований. -2009 . - № 4. - С. 28.

5. Калашник, В. В. Проповедническая и публицистическая деятельность духовенства Русской православной церкви в годы Великой Отечественной войны (1941-1945 гг.) / В. В. Калашник // Исторические, философские, политические и юридические науки, культурология и искусствоведение. Вопросы теории и практики. -2017 . - № 3 (77), ч. 2. - С. 67-74.

6. Ковалев, Б. Повседневная жизнь населения России в период нацистской оккупации / Б. Ковалев. -М. : Молодая гвардия, 2011. - 656 с.

7. Кринко, Е. Ф. Религиозная жизнь в тылу и на фронте в годы Великой Отечественной войны 


\section{СТАЛИНГРАДСКИЙ ТЫЛ}

/ Е. Ф. Кринко // Вестник Оренбургского государственного педагогического университета : электрон. науч. журн. - 2015. - № 1 (13).

8. Кулик, С. В. Участие православного духовенства в движении советского сопротивления на оккупированной территории северо-запада России в 1941-1944 гг. / С. В. Кулик, Е. А. Самыловская // Научно-технические ведомости Санкт-Петербургского государственного политехнического университета. Гуманитарные и общественные науки. 2016. - № 2 (244). - С. 59-65.

9. Мордвинов, С. В. Патриотическая деятельность православного духовенства и верующих нижней Волги в 1941-1945 годы / С. В. Мордвинов // Военная история России: проблемы, поиски, решения : материалы Междунар. науч. конф., посвящ. 70-летию Победы в Великой Отечественной войне. В 2 ч. Ч. 1. - Волгоград : Изд-во ВолГУ, 2015. - C. 63-73.

10. Мордвинов, С. В. Православное возрождение на Нижней Волге и Дону в 1942 - 1943 гг. / С. В. Мордвинов // Вестник Волгоградского университета. Серия 4, История. Регионоведение. Международные отношения - 2013. - № 1 (23). - C. 20-25. - DOI: http://dx.doi.org/10.15688/jvolsu4.2013.1.3.

11. Назарова, О.В.Они прошли войну с верой: православное духовенство в битве за Сталинград / О. В. Назарова // Великая Отечественная война 1941-1945 гг. в судьбах народов и регионов : сб. ст. Казань : Институт истории им. Ш. Марджани АН PT, 2015. - C. 443-451.

12. Платон (Рожков С. В.), иеродиакон. Духовенство Русской православной церкви на оккупированных территориях СССР в период Великой Отечественной войны 1941-1945 гг. / иеродиакон Платон (Рожков С. В.) // Вестник архивиста. - 2015. № 3. - С. 211-228.

13. Регистрационное дело Вознесенского молитвенного дома с. Круглое // ГАРО. - Ф. Р-4173. Оп. 6. - Д. 97. - 313 л.

14. Регистрационное дело Всехсвятской кладбищенской церкви г. Таганрога. Т. 1 // ГАРО. Ф. Р-4173. - Оп. 6. - Д. 77. - 327 л.

15. Регистрационное дело Георгиевского молитвенного дома г. Таганрога. Т. 1 // ГАРО. Ф. Р-4173. - Оп. 6. - Д. 79. - 308 л.

16. Регистрационное дело на Александро-Невскую церковь г. Азов Ростовская обл. // ГАРО. Ф. Р-4173. - Оп. 4. - Д. 59. - 69 л.

17. Регистрационное дело на Александро-Невскую церковь г. Шахты Ростовская обл. // ГАРО. Ф. Р-4173. - Оп. 4. - Д. 91. - 480 л.

18. Регистрационное дело на Вознесенский молитвенный дом с. Федоровка Таганрогский с/с Ростовская обл. // ГАРО. - Ф. Р-4173. - Оп. 4. Д. 264. - 191 л.
19. Регистрационное дело на Георгиевскую церковь г. Новочеркасска. Т. 1 // ГАРО. - Ф. Р-4173. Оп. 6. - Д. 62. - 267 л.

20. Регистрационное дело на Георгиевскую церковь с. Сандата Сальский р-н Ростовская обл. // ГАРО. - Ф. Р-4173. - Оп. 4. - Д. 258. - 247 л.

21. Регистрационное дело на Димитриевскую кладбищенскую церковь г. Новочеркасска // ГАРО. Ф. Р-4173. - ОП. 6. - Д. 64. - 379 Л.

22. Регистрационное дело на Казанскую церковь с. Кичкино Заветинский р-н Ростовская обл. // ГАРО. - Ф. Р-4173. - Оп. 4. - Д. 70. - 47 л.

23. Регистрационное дело на КонстантиноЕленинскую церковь г. Новочеркасска // ГАРО. Ф. Р-4173. - Оп. 6. - Д. 65. - 291 л.

24. Регистрационное дело на Кресто-Воздвиженский молитвенный дом г. Таганрог Ростовская обл. // Государственный архив Ростовской области (ГАРО). - Ф. Р-4173. - Оп. 4. - Д. 57. - 336 л.

25. Регистрационное дело на Крестовоздвиженский молитвенный дом хут. Роги Тарасовский р-н Ростовская обл. // ГАРО. - Ф. Р-4173. - Оп. 4. Д. 269. - 190 л.

26. Регистрационное дело на молитвенный дом свв. Кирилла и Мефодия ст. Буденовская Пролетарский сельский р-н Ростовская обл. // ГАРО. Ф. Р-4173. - Оп. 4. - Д. 250. - 116 л.

27. Регистрационное дело на Николаевскую церковь хут. Пичугин Советский р-н Ростовская обл. // ГАРО. - Ф. Р-4173. - Оп. 4. - Д. 261. - 103 л.

28. Регистрационное дело на Никольский молитвенный дом г. Батайск Ростовская обл. // ГАРО. Ф. Р-4173. - Оп. 4. - Д. 181. - 303 л.

29. Регистрационное дело на Никольский молитвенный дом с. Заветное Заветинский р-н Ростовская обл. // ГАРО. - Ф. Р-4173. - Оп. 6. - Д. 120. - 150 л.

30. Регистрационное дело на Никольскую церковь г. Шахты. Т. 1 // ГАРО. - Ф. Р-4173. - Оп. 6. Д. 88. -424 л.

31. Регистрационное дело на Одигитриевский молитвенный дом хут. Ново-Павловка Тацинский p-н Ростовская обл. // ГАРО. - Ф. Р-4173. - Оп. 4. Д. $82 .-37$ л.

32. Регистрационное дело на Покровский молитвенный дом с. Покровское Неклиновский р-н Ростовская обл. // ГАРО. -Ф. Р-4173. - Оп. 6. - Д. 152. -381 л.

33. Регистрационное дело на Покровскую церковь хут. Яново-Шептуховка Чертковский р-н Ростовская обл. // ГАРО. - Ф. Р-4173. - Оп. 6. - Д. 189. 348 л.

34. Регистрационное дело на Троицкую церковь с. Ивановка Таганрогский с/с Ростовская обл. // ГАРО. - Ф. Р-4173. - Оп. 4. - Д. 262. - 93 л.

35. Регистрационное дело на Троицкую церковь хут. Качалин Тацинский р-н // ГАРО. - Ф. Р-4173. Оп. 4. - Д. 129. - 143 л. 
36. Регистрационное дело на Успенский молитвенный дом с. Баранники Сальский р-н Ростовская обл. // ГАРО. - Ф. Р-4173. - Оп. 4. - Д. 257. - 110 л.

37. Регистрационное дело на Успенский молитвенный дом с. Латоново Матвеево-Курганского района // ГАРО. - Ф. Р-4173. - Оп. 4. - Д. 195. - 135 л.

38. Регистрационное дело на Успенский молитвенный дом с. Первомайское Ремонтненский р-н, Ростовская обл. // ГАРО. - Ф. Р-4173. - ОП. 4. Д. 251. -190 л.

39. Регистрационное дело на Успенский молитвенный дом. г. Азов. Ростовская обл. Т.1 // ГАРО. Ф. Р-4173. - Оп. 4. - Д. 184. - 306 л.

40. Регистрационное дело на Успенскую церковь ст. Калитвенская Каменский р-н Ростовская обл. // ГАРО. - Ф. Р-4173. - Оп. 4. - Д. 232. - 232 л.

41. Регистрационное дело на церковь Всех святых. г. Ростов-на-Дону Ленинский р-н. Т. 1. // ГАРО.Ф. Р-4173. - Оп. 4. - Д. 175. - 448 л.

42. Регистрационное дело на церковь иконы Божией Матери Живоносный Источник с. Петровское Неклиновский р-н Ростовская обл. // ГАРО. Ф. Р-4173. - Оп. 4. - Д. 116. - 176 л.

43. Регистрационное дело на церковь Рождества Богородицы хут. Крюково Куйбышевский р-н, Ростовская обл. // ГАРО. - Ф. Р-4173. - ОП. 4. Д. $103 .-145$ л.

44. Регистрационное дело на церковь св. Иоанна Богослова хут. Мостовой Раздорский р-н Ростовская обл. // ГАРО. - Ф. Р-4173. - Оп. 4. - Д. 277. 118 л.

45. Регистрационное дело Покровского молитвенного дома г. Шахты. Т. 1 // ГАРО. - Ф. Р-4173. Оп. 6. - Д. 90. - 338 л.

46. Редькина, О. Ю. Власть и Церковь в 19431951 гг.: проблема церковной патриотической благотворительности (на материалах Нижней Волги и Дона) / О. Ю. Редькина // Власть: общенац. науч.полит. журн. - 2012. - № 4. - С. 118-121.

47. Редькина, О. Ю. Православное духовенство Нижней Волги и Дона а 1940-1953 гг. / О. Ю. Редькина, С. В. Мордвинов // Вестник Волгоградского государственного университета. Серия 4, История. Регионоведение. Международные отношения 2014. - № 6 (30). - C. 81-90. - DOI: http://dx.doi.org/ 10.15688/jvolsu4.2014.6.9.

48. Русская православная церковь в годы Великой Отечественной войны 1941-1945 гг. : сб. док. / сост. О. Ю. Васильева, И. И. Кудрявцев, Л. А. Лыкова - М. : Изд-во Крутицкого подворья, 2009. C. 295.

49. Русская Православная Церковь и Великая Отечественная война. Сборник церковных документов. - М. : [б. и.], 1943. -100 с.

50. Русская Православная Церковь и коммунистическое государство. 1917-1941 : док. и фотома- териалы. - М. : Изд-во Библейско-Богословского инта св. апостола Андрея, 1996. - 352 с.

51. Снова в Таганроге Пасха // Новое слово. 1942. - 5 апр. (№ 27 (30)). - С. 1.

52. Справка о количественном составе церквей и молитвенных домов области с отметкой о дате закрытия церквей // ГАРО. - Ф. Р-4173. - Оп. 5. Д. 2. -48 л.

53. Табунщикова, Л. В. Количественный анализ открытия православных храмов и молитвенных домов на оккупированной территории Ростовской области в годы Великой Отечественной войны / Л.В.Табунщикова // Исторические, философские, политические и юридические науки, культурология и искусствоведение. Вопросы теории и практики. - 2015. - № 10 (60), ч. I. - С. 172-174.

54. Табунщикова, Л. В. Особенности церковной жизни на территории Ростовской области в период немецкой оккупации в годы Великой Отечественной войны / Л. В. Табунщикова // Исторические, философские, политические и юридические науки, культурология и искусствоведение. Вопросы теории и практики. - 2015. - № 10 (60), ч. 1. С. $175-178$.

55. Табунщикова, Л. В. Патриотическая деятельность религиозных организаций на территории Ростовской области в годы Великой Отечественной войны / Л. В. Табунщикова // Известия СОИГСИ. 2015. - Вып. 14. - С. 92-96.

56. Табунщикова, Л. В. Церковная жизнь г. Ростова-на-Дону в период немецкой оккупации в годы Великой Отечественной войны / Л. В. Табунщикова // Актуальные проблемы социальной истории. 2016. - Вып. 17. - С. 81-86.

57. Табунщикова, Л. В. Церковная жизнь на территории Ростовской области в период немецкой оккупации в годы Великой Отечественной войны / Л. В. Табунщикова // Значение сражений 19411943 гг. на Юге России в победе в Великой Отечественной войне : материалы Всерос. науч. конф. (г. Ростов-на-Дону, 3-6 июня 2015). - Ростов н/Д : Изд-во ЮНЦ РАН, 2015. - С. 369-375.

58. Церкви Ростова // Голос Ростова. - 1942. № 16. - С. 1 .

59. Шадрина, А. В. Священнослужители Ростовской области в годы Великой Отечественной войны / А. В. Шадрина // Значение сражений 19411943 гг. на Юге России в победе в Великой Отечественной войне: материалы Всерос. науч. конф. (г. Ростов-на-Дону, 3-6 июня 2015 г.) / отв. ред. акад. Г. Г. Матишов. - Ростов н/Д : Изд-во ЮНЦ РАН, 2015. - С. 231-237.

60. Шкаровский, М. В. Русская православная церковь и другие конфессии Советского Союза в годы Великой Отечественной войны (историографический и источниковедческий обзор) / М. В. Шка- 


\section{СТАЛИНГРАДСКИЙ ТЫЛ}

ровский // История и историки: историографический вестник. - 2013. - Т. 2011-2012, № 1. - С. 32-89.

61. Шкаровский, М. В. Русская церковь и Третий рейх / М. В. Шкаровский. - М : Вече, 2010. $464 \mathrm{c}$.

62. Якунин, В. Н. Русская Православная церковь в годы Великой Отечественной войны 19411945 гг.: историография и источниковедение проблемы / В. Н. Якунин - Тольятти : Современник, 2002. $-167 \mathrm{c}$.

63. Shadrina, A.V. Questionnaires of the Clergymen of the Rostov Region of the 1940s and 1950s: Description of the Social Group / A.V. Shadrina // Русский архив. - 2015. - № 9. - Р. 236-252.

\section{REFERENCES}

1. Babicheva O.A. Prosvetitelskaya deyatelnost i pastyrskoe sluzhenie pravoslavnogo dukhovenstva v gody Velikoy Otechestvennoy voyny [Educational Activities and Pastoral Service of the Orthodox Clergy During the Great Patriotic War]. Vestnik magistratury, 2016, no. 12 (63), pp. 49-52.

2. Vechnaya pamyat ubiennym [Eternal Memory to the Murdered]. Golos Rostova [The Voice of Rostov], 1942, no. 8, p. 1.

3. Galkin A.K. Ukazy $i$ opredeleniya Moskovskoy Patriarkhii ob arkhiereyakh s nachala Velikoy Otechestvennoy voyny do Sobora $1943 \mathrm{~g}$. [Decrees and Resolutions of the Moscow Patriarchate on Bishops from the Beginning of the Great Patriotic War to the Council of 1943]. URL: http://www. sedmitza.ru/text/413984.html (accessed July 20, 2015).

4. Zhuravlev E.I. Nemetskiy okkupatsionnyy rezhim i religioznyy vopros na Yuge Rossii v gody Velikoy Otechestvennoy voyny [German Occupation Regime and Religious Issue in the South of Russia During the Great Patriotic War]. Nauchnye problemy gumanitarnykh issledovaniy, 2009, no. 4, p. 28.

5. Kalashnik V.V Propovednicheskaya i publitsisticheskaya deyatelnost dukhovenstva Russkoy pravoslavnoy tserkvi v gody Velikoy Otechestvennoy voyny (1941-1945 gg.) [Preaching and Publicistic Activity of the Clergy of the Russian Orthodox Church During the Great Patriotic War (1941-1945)]. Istoricheskie, filosofskie, politicheskie i yuridicheskie nauki, kulturologiya $i$ iskusstvovedenie. Voprosy teorii $i$ praktiki, 2017, no. 3 (77), part 2, pp. 67-74.

6. Kovalev B. Povsednevnaya zhizn naseleniya Rossii v period natsistskoy okkupatsii [Daily Life of the Russian Population During the Nazi Occupation]. Moscow, Molodaya gvardiya Publ., 2011. 656 p.

7. Krinko E.F. Religioznaya zhizn v tylu i na fronte v gody Velikoy Otechestvennoy voyny [Religious Life in the Rear and at the Front During the Great Patriotic
War]. Vestnik Orenburgskogo gosudarstvennogo pedagogicheskogo universiteta: elektron. nauch. zhurn., 2015, no. 1 (13).

8. Kulik S.V., Samylovskaya E.A. Uchastie pravoslavnogo dukhovenstva $\mathrm{v}$ dvizhenii sovetskogo soprotivleniya na okkupirovannoy territorii severozapada Rossii v 1941-1944 gg. [The Participation of the Orthodox Clergy in the Movement of Soviet Resistance in the Occupied Territory of North-West Russia in 1941- 1944]. Nauchno-tekhnicheskie vedomosti Sankt-Peterburgskogo gosudarstvennogo politekhnicheskogo universiteta. Gumanitarnye $i$ obshchestvennye nauki, 2016, no. 2 (244), pp. 59-65.

9. Mordvinov S.V. Patrioticheskaya deyatelnost pravoslavnogo dukhovenstva i veruyushchikh nizhney Volgi v 1941-1945 gody [Patriotic Activity of the Orthodox Clergy and Believers of the Lower Volga in 1941-1945]. Voennaya istoriya Rossii: problemy, poiski, resheniya: materialy Mezhdunar. nauch. konf., posvyashch. 70-letiyu Pobedy v Velikoy Otechestvennoy voyne. V 2 ch. Ch. 1 [Military History of Russia: Problems, Searches, Solutions: Proceedings of the International Academic Conference Devoted to the $70^{\text {th }}$ Anniversary of Victory in the Great Patriotic War. In 2 Parts. Part 1]. Volgograd, Izd-vo VolGU, 2015, pp. 63-73.

10. Mordvinov S.V. Pravoslavnoe vozrozhdenie na Nizhney Volge i Donu v 1942 - 1943 gg. [Orthodox Revival on the Lower Volga and the Don in 1942-1943]. Vestnik Volgogradskogo universiteta. Seriya 4, Istoriya. Regionovedenie. Mezhdunarodnye otnosheniya [Science Journal of Volgograd State University. History. Area Studies. International Relations], 2013, no. 1 (23), pp. 20-25. DOI: http:// dx.doi.org/10.15688/jvolsu4.2013.1.3.

11. Nazarova O.V. Oni proshli voynu s veroy: pravoslavnoe dukhovenstvo v bitve za Stalingrad [They Lived Through the War with Faith: the Orthodox Clergy in the Battle of Stalingrad]. Velikaya Otechestvennaya voyna 1941-1945 gg. v sudbakh narodov i regionov: sb. st. [The Great Patriotic War of 1941-1945 in the Destinies of Peoples and Regions: Collected Articles]. Kazan, Institut istorii im. Sh. Mardzhani AN RT, 2015, pp. 443-451.

12. Platon (Rozhkov S.V.), ierodiakon. Dukhovenstvo Russkoy pravoslavnoy tserkvi na okkupirovannykh territoriyakh SSSR v period Velikoy Otechestvennoy voyny 1941-1945 gg. [The Clergy of the Russian Orthodox Church in the Occupied Territories of the USSR During the Great Patriotic War of 19411945]. Vestnik arkhivista, 2015, no. 3, pp. 211-228.

13. Registratsionnoe delo Voznesenskogo molitvennogo doma s. Krugloe [Registration File of the Ascension Prayer House, Krugloe Village]. Gosudarstvennyy arkhiv Rostovskoy oblasti [State Archive of the Rostov Region], F. R-4173, Op. 6, D. 97.3131 . 
14. Registratsionnoe delo Vsekhsvyatskoy kladbishchenskoy tserkvi g. Taganroga. T. 1 [Registration File of the All-Saints Cemetery Church in Taganrog. Vol. 1] Gosudarstvennyy arkhiv Rostovskoy oblasti [State Archive of the Rostov Region], F. R-4173, Op. 6, D. 77, 3271.

15. Registratsionnoe delo Georgievskogo molitvennogo doma g. Taganroga. T. 1 [Registration File of the St. George's Prayer House in Taganrog. Vol. 1] Gosudarstvennyy arkhiv Rostovskoy oblasti [State Archive of the Rostov Region], F. R-4173, Op. 6, D. 79.3081 .

16. Registratsionnoe delo na AleksandroNevskuyu tserkov g. Azov Rostovskaya obl. [Registration File of the Alexander Nevsky Church in the City of Azov, Rostov Region]. Gosudarstvennyy arkhiv Rostovskoy oblasti [State Archive of the Rostov Region], F. R-4173, Op. 4, D. 59. 691.

17. Registratsionnoe delo na AleksandroNevskuyu tserkov g. Shakhty Rostovskaya obl. [Registration File of the Alexander Nevsky Church in the City of Shakhty, Rostov Region]. Gosudarstvennyy arkhiv Rostovskoy oblasti [State Archive of the Rostov Region], F. R-4173, Op. 4, D. 91.4801.

18. Registratsionnoe delo na Voznesenskiy molitvennyy dom s. Fedorovka Taganrogskiy s/s Rostovskaya obl. [Registration File of the Ascension Prayer House, Fedorovka Village, Rostov Region]. Gosudarstvennyy arkhiv Rostovskoy oblasti [State Archive of the Rostov Region], F. R-4173, Op. 4, D. 264. 1911.

19. Registratsionnoe delo na Georgievskuyu tserkov g. Novocherkasska. T. 1 [Registration File of St. George's Church in Novocherkassk. Vol. 1]. Gosudarstvennyy arkhiv Rostovskoy oblasti [State Archive of the Rostov Region], F. R-4173, Op. 6, D. 62.2671.

20. Registratsionnoe delo na Georgievskuyu tserkov s. Sandata Salskiy r-n Rostovskaya obl. [Registration File of St. George Church, Sandata Village, Salsky District, Rostov Region]. Gosudarstvennyy arkhiv Rostovskoy oblasti [State Archive of the Rostov Region], F. R-4173, Op. 4, D. 258. 2471.

21. Registratsionnoe delo na Dimitrievskuyu kladbishchenskuyu tserkov g. Novocherkasska [Registration File of the Dimitrievskaya Cemetery Church in Novocherkassk]. Gosudarstvennyy arkhiv Rostovskoy oblasti [State Archive of the Rostov Region], F. R-4173, Op. 6, D. 64. 3791.

22. Registratsionnoe delo na Kazanskuyu tserkov s. Kichkino Zavetinskiy r-n Rostovskaya obl. [Registration File of the Kazan Church, Kichkino Village, Zavetinskiy District, Rostov Region]. Gosudarstvennyy arkhiv Rostovskoy oblasti [State Archive of the Rostov Region], F. R-4173, Op. 4, D. 70.471 .
23. Registratsionnoe delo na KonstantinoEleninskuyu tserkov g. Novocherkasska [Registration File of the Konstantin-Eleninskaya Church in Novocherkassk]. Gosudarstvennyy arkhiv Rostovskoy oblasti [State Archive of the Rostov Region], F. R-4173, Op. 6, D. 65. 2911.

24. Registratsionnoe delo na KrestoVozdvizhenskiy molitvennyy dom g. Taganrog Rostovskaya obl. [Registration File of the KrestoVozdvizhensky Prayer House in Taganrog, Rostov Region]. Gosudarstvennyy arkhiv Rostovskoy oblasti [State Archive of the Rostov Region], F. R-4173, Op. 4, D. 57.3361.

25. Registratsionnoe delo na Krestovozdvizhenskiy molitvennyy dom khut. Rogi Tarasovskiy r-n Rostovskaya obl. [Registration File of the Krestovozdvizhensky Prayer House of Rogi Hamlet, Tarasovsky District, Rostov Region]. Gosudarstvennyy arkhiv Rostovskoy oblasti [State Archive of the Rostov Region], F. R-4173, Op. 4, D. 269. 1901.

26. Registratsionnoe delo na molitvennyy dom svv. Kirilla i Mefodiya st. Budenovskaya Proletarskiy selskiy r-n Rostovskaya obl. [Registration File of the Prayer House of Saints Cyril and Methodius, Budenovskaya Village, Proletarsky District, Rostov Region]. Gosudarstvennyy arkhiv Rostovskoy oblasti [State Archive of the Rostov Region], F. R-4173, Op. 4, D. 250.1161.

27. Registratsionnoe delo na Nikolaevskuyu tserkov khut. Pichugin Sovetskiy r-n Rostovskaya obl. [Registration File of the Nikolayevskaya Church of Pichugin Hamlet, Sovetsky District, Rostov Region]. Gosudarstvennyy arkhiv Rostovskoy oblasti [State Archive of the Rostov Region], F. R-4173, Op. 4, D. 261. 1031 .

28. Registratsionnoe delo na Nikolskiy molitvennyy dom g. Bataysk Rostovskaya obl. [Registration File at the Nikolsky Prayer House in Bataysk, Rostov Region]. Gosudarstvennyy arkhiv Rostovskoy oblasti [State Archive of the Rostov Region], F. R-4173, Op. 4, D. 181. 3031.

29. Registratsionnoe delo na Nikolskiy molitvennyy dom s. Zavetnoe Zavetinskiy r-n Rostovskaya obl. [Registration file at the Nikolsky Prayer House, Zavetnoye Village, Zavetinsky District, Rostov Region]. Gosudarstvennyy arkhiv Rostovskoy oblasti [State Archive of the Rostov Region], F. R-4173, Op. 6, D. 120. 1501.

30. Registratsionnoe delo na Nikolskuyu tserkov g. Shakhty. T. 1 [Registration File of the St. Nicholas Church in Shakhty. Vol. 1]. Gosudarstvennyy arkhiv Rostovskoy oblasti [State Archive of the Rostov Region], F. R-4173, Op. 6, D. 88. 4241.

31. Registratsionnoe delo na Odigitrievskiy molitvennyy dom khut. Novo-Pavlovka Tatsinskiy r-n Rostovskaya obl. [Registration File of the Odigitriev 


\section{СТАЛИНГРАДСКИЙ ТЫЛ}

Prayer House of the Novo-Pavlovka Hamlet, Tatsinsky District, Rostov Region]. Gosudarstvennyy arkhiv Rostovskoy oblasti [State Archive of the Rostov Region], F. R-4173, Op. 4, D. 82. 371.

32. Registratsionnoe delo na Pokrovskiy molitvennyy dom s. Pokrovskoe Neklinovskiy r-n Rostovskaya obl. [Registration File of the Pokrovskiy Prayer House, Pokrovskoe Village, Neklinovskiy District, Rostov Region]. Gosudarstvennyy arkhiv Rostovskoy oblasti [State Archive of the Rostov Region], F. R-4173, Op. 6, D. 152. 3811.

33. Registratsionnoe delo na Pokrovskuyu tserkov khut. Yanovo-Sheptukhovka Chertkovskiy r-n Rostovskaya obl. [Registration File of the Pokrovskaya Church, Yanovo-Sheptuhovka Hamlet, Chertkovsky District, Rostov Region]. Gosudarstvennyy arkhiv Rostovskoy oblasti [State Archive of the Rostov Region], F. R-4173, Op. 6, D. 189. 3481.

34. Registratsionnoe delo na Troitskuyu tserkov s. Ivanovka Taganrogskiy s/s Rostovskaya obl. [Registration File of the Trinity Church in the Village of Ivanovka, Taganrogskiy Settlement, Rostov Region]. Gosudarstvennyy arkhiv Rostovskoy oblasti [State Archive of the Rostov Region], F. R-4173, Op. 4, D. 262.931.

35. Registratsionnoe delo na Troitskuyu tserkov khut. Kachalin Tatsinskiy r-n [Registration File of the Trinity Church of the Kachalin Farm, Tatsinsky District]. Gosudarstvennyy arkhiv Rostovskoy oblasti [State Archive of the Rostov Region], F. R-4173, Op. 4, D. 129.1431

36. Registratsionnoe delo na Uspenskiy molitvennyy dom s. Baranniki Salskiy r-n Rostovskaya obl. [Registration File of the Uspensky Prayer House in the Village of Baraniki, Salsky District, Rostov Region]. Gosudarstvennyy arkhiv Rostovskoy oblasti [State Archive of the Rostov Region], F. R-4173, Op. 4, D. 257. 1101 .

37. Registratsionnoe delo na Uspenskiy molitvennyy dom s. Latonovo Matveevo-Kurganskogo rayona [Registration File of the Uspensky Prayer House, Latonovo Village, Matveevo-Kurgan District]. Gosudarstvennyy arkhiv Rostovskoy oblasti [State Archive of the Rostov Region], F. R-4173, Op. 4, D. 195.1351.

38. Registratsionnoe delo na Uspenskiy molitvennyy dom s. Pervomayskoe Remontnenskiy r-n, Rostovskaya obl. [Registration File of the Uspensky Prayer House, Pervomayskoe Village, Remontnenskiy District, Rostov Region]. Gosudarstvennyy arkhiv Rostovskoy oblasti [State Archive of the Rostov Region], F. R-4173, Op. 4, D. 251. 1901.

39. Registratsionnoe delo na Uspenskiy molitvennyy dom. g. Azov. Rostovskaya obl. T.1 [Registration File of the Uspenskiy Prayer House in the City of Azov. The Rostov Region. Vol. 1].
Gosudarstvennyy arkhiv Rostovskoy oblasti [State Archive of the Rostov Region], F. R-4173, Op. 4, D. 184. 3061 .

40. Registratsionnoe delo na Uspenskuyu tserkov st. Kalitvenskaya Kamenskiy r-n Rostovskaya obl. [Registration File of the Uspenskaya Church, Kalitvenskaya Village, Kamensky District, Rostov Region]. Gosudarstvennyy arkhiv Rostovskoy oblasti [State Archive of the Rostov Region], F. R-4173, Op. 4, D. 232. 2321.

41. Registratsionnoe delo na tserkov Vsekh svyatykh. g. Rostov-na-Donu Leninskiy r-n. T. 1. [Registration File of the Church of All Saints. Rostovon-Don, Leninsky District. Vol. 1] Gosudarstvennyy arkhiv Rostovskoy oblasti [State Archive of the Rostov Region], F. R-4173, Op. 4, D. 175. 4481.

42. Registratsionnoe delo na tserkov ikony Bozhiey Materi Zhivonosnyy Istochnik s. Petrovskoe Neklinovskiy r-n Rostovskaya obl. [Registration File of the Church of the Icon Mother of God Life-Giving Source of the Petrovskoe Village, Neklinovsky District, Rostov Region]. Gosudarstvennyy arkhiv Rostovskoy oblasti [State Archive of the Rostov Region], F. R-4173, Op. 4, D. 116. 1761.

43. Registratsionnoe delo na tserkov Rozhdestva Bogoroditsy khut. Kryukovo Kuybyshevskiy r-n, Rostovskaya obl. [Registration File of the Church of the Nativity of the Blessed Virgin, Kryukovo Hamlet, Kuibyshev District, Rostov Region]. Gosudarstvennyy arkhiv Rostovskoy oblasti [State Archive of the Rostov Region], F. R-4173, Op. 4, D. 103. 1451.

44. Registratsionnoe delo na tserkov sv. Ioanna Bogoslova khut. Mostovoy Razdorskiy r-n Rostovskaya obl. [Registration File of the Church of St. Ioann Bogoslov, Mostovoy Hamlet, Razdorskiy District, Rostov Region]. Gosudarstvennyy arkhiv Rostovskoy oblasti [State Archive of the Rostov Region], F. R-4173, Op. 4, D. 277. 1181.

45. Registratsionnoe delo Pokrovskogo molitvennogo doma g. Shakhty. T. 1 [Registration File of Pokrovsky Prayer House in the City of Shakhty]. Gosudarstvennyy arkhiv Rostovskoy oblasti [State Archive of the Rostov Region], F. R-4173, Op. 6, D. 90.3381 .

46. Redkina O.Yu. Vlast i Tserkov v 1943-1951 gg.: problema tserkovnoy patrioticheskoy blagotvoritelnosti (na materialakh Nizhney Volgi i Dona) [Power and the Church in 1943-1951: the Problem of Church Patriotic Charity (on the Materials of the Lower Volga and the Don)]. Vlast: obshchenats. nauch.-polit. zhurn., 2012 , no. 4, pp. 118-121.

47. Redkina O.Yu., Mordvinov S.V. Pravoslavnoe dukhovenstvo Nizhney Volgi i Dona v 1940-1953 gg. [The Orthodox Clergy of the Lower Volga and the Don in 1940-1953]. Vestnik Volgogradskogo universiteta. Seriya 4, Istoriya. Regionovedenie. Mezhdunarodnye 
otnosheniya [Science Journal of Volgograd State University. History. Area Studies. International Relations], 2014, no. 6 (30), pp. 81-90. DOI: http:// dx.doi.org/10.15688/jvolsu4.2014.6.9.

48. Vasilyeva O.Yu., Kudryavtsev I.I., Lykova L.A. Russkaya pravoslavnaya tserkov $v$ gody Velikoy Otechestvennoy voyny 1941-1945 gg.: sb. dok. [The Russian Orthodox Church During the Great Patriotic War of 1941-1945. Collected Documents]. Moscow, Izd-vo Krutitskogo podvorya, 2009, p. 295.

49. Russkaya Pravoslavnaya Tserkovi Velikaya Otechestvennaya voyna. Sbornik tserkovnykh dokumentov [Russian Orthodox Church and Great Patriotic War. Collection of church documents]. Moscow, 1943. 100 p.

50. Russkaya Pravoslavnaya Tserkov $i$ kommunisticheskoe gosudarstvo, 1917-1941: dok. $i$ fotomaterialy [The Russian Orthodox Church and the Communist State. 1917-1941. Documents and Photographic Materials]. Moscow, Izd-vo BibleyskoBogoslovskogo in-ta sv. apostola Andreya, 1996. 352 p.

51. Snova v Taganroge Paskha [Taganrog Celebrates Easter Again]. Novoe slovo, 1942, April 5, no. 27 (30), p. 1.

52. Spravka o kolichestvennom sostave tserkvey i molitvennykh domov oblasti s otmetkoy o date zakrytiya tserkvey [Reference on the Quantity of Churches and Prayer Houses of the Region with a Note about the Closing Date of Churches]. Gosudarstvennyy arkhiv Rostovskoy oblasti [State Archive of the Rostov Region], F. R-4173, Op. 5, D. 2. 481.

53. Tabunshchikova L.V. Kolichestvennyy analiz otkrytiya pravoslavnykh khramov i molitvennykh domov na okkupirovannoy territorii Rostovskoy oblasti v gody Velikoy Otechestvennoy voyny [Quantitative Analysis of the Opening of Orthodox Churches and Prayer Houses in the Occupied Territory of the Rostov Region During the Great Patriotic War]. Istoricheskie, filosofskie, politicheskie i yuridicheskie nauki, kulturologiya i iskusstvovedenie. Voprosy teorii $i$ praktiki, 2015, no. 10 (60), part 1, pp. 172-174.

54. Tabunshchikova L.V. Osobennosti tserkovnoy zhizni na territorii Rostovskoy oblasti v period nemetskoy okkupatsii v gody Velikoy Otechestvennoy voyny [Features of Church Life in the Territory of the Rostov Region During the German Occupation in the Great Patriotic War]. Istoricheskie, filosofskie, politicheskie i yuridicheskie nauki, kulturologiya i iskusstvovedenie. Voprosy teorii $i$ praktiki, 2015, no. 10 (60), part 1, pp. 175-178.

55. Tabunshchikova L.V. Patrioticheskaya deyatelnost religioznykh organizatsiy na territorii Rostovskoy oblasti v gody Velikoy Otechestvennoy voyny [Patriotic Activity of Religious Organizations in the Territory of the Rostov Region During the Great Patriotic War]. Izvestiya SOIGSI, 2015, iss. 14, pp. 92-96.
56. Tabunshchikova L.V. Tserkovnaya zhizn g. Rostova-na-Donu v period nemetskoy okkupatsii v gody Velikoy Otechestvennoy voyny [The Church Life of Rostov-on-Don During the German Occupation in the Great Patriotic War]. Aktualnye problemy sotsialnoy istorii, 2016, iss. 17, pp. 81-86.

57. Tabunshchikova L.V. Tserkovnaya zhizn na territorii Rostovskoy oblasti $\mathrm{v}$ period nemetskoy okkupatsii v gody Velikoy Otechestvennoy voyny [Church Life in the Territory of the Rostov Region During the German Occupation in the Great Patriotic War]. Matishov G.G., ed. Znachenie srazheniy 19411943 gg. na Yuge Rossii v pobede v Velikoy Otechestvennoy voyne: materialy Vseros. nauch. konf. (g. Rostov-na-Donu, 3-6 iyunya 2015) [The Importance of Fights of 1941-1943 in the South of Russia for the Victory in the Great Patriotic War: Proceedings of the All-Russian Academic Conference (Rostov-on-Don, June 3-6, 2015)]. Rostov-on-Don, Izd-vo YuNTs RAN, 2015, pp. 369-375.

58. Tserkvi Rostova [Churches of Rostov]. Golos Rostova [The Voice of Rostov], 1942, no. 16, p. 1.

59. Shadrina A.V. Svyashchennosluzhiteli Rostovskoy oblasti v gody Velikoy Otechestvennoy voyny [Priests of the Rostov region during the Great Patriotic War]. Matishov G.G., ed. Znachenie srazheniy 1941-1943 gg. na Yuge Rossii v pobede v Velikoy Otechestvennoy voyne: materialy Vseros. nauch. konf. (g. Rostov-na-Donu, 3-6 iyunya 2015 g.) [The Importance of Fights of 1941-1943 in the South of Russia for the Victory in the Great Patriotic War: Proceedings of the All-Russian Academic Conference (Rostov-on-Don, June 3-6, 2015)]. Rostov-on-Don, Izd-vo YuNTs RAN, 2015, pp. 231-237.

60. Shkarovskiy M.V. Russkaya pravoslavnaya tserkov i drugie konfessii Sovetskogo Soyuza v gody Velikoy Otechestvennoy voyny (istoriograficheskiy i istochnikovedcheskiy obzor) [Russian Orthodox Church and Other Confessions of the Soviet Union During the Great Patriotic War (Historiographical and Source Study Review)]. Istoriya $i$ istoriki: istoriograficheskiy vestnik, 2013, vol. 2011-2012, no. 1, pp. 32-89.

61. Shkarovskiy M.V. Russkaya tserkov i Tretiy reykh [The Russian Church and the Third Reich]. Moscow, Veche Publ., 2010. 464 p.

62. Yakunin V.N. Russkaya Pravoslavnaya tserkov v gody Velikoy Otechestvennoy voyny 1941-1945 gg.: istoriografiya i istochnikovedenie problemy [Russian Orthodox Church During the Great Patriotic War of 1941-1945: Historiography and Source Study of the Problem]. Togliatti, Sovremennik Publ., 2002. 167 p.

63. Shadrina A.V. Questionnaires of the Clergymen of the Rostov Region of the 1940s and 1950s: Description of the Social Group. Russkiy arkhiv, 2015, no. 9, pp. 236-252. 


\section{Information about the Author}

Alla V. Shadrina, Candidate of Sciences (History), Researcher, Southern Scientific Center of RAS, Prosp. Chekhova, 41, 344006 Rostov-on-Don, Russian Federation, shadrina@ssc-ras.ru, https:// orcid.org/0000-0002-1925-0216

\section{Информация об авторе}

Алла Валерьевна Шадрина, кандидат исторических наук, научный сотрудник, Южный научный центр РАН, просп. Чехова, 41, 344006 г. Ростов-на-Дону, Российская Федерация, shadrina@ssc-ras.ru, https://orcid.org/0000-0002-1925-0216 